\title{
Using Heights to Trace Living Standards and Inequality in Mexico Since 1850
}

\author{
Moramay López-Alonso and Roberto Vélez-Grajales
}

\section{Introduction}

Mexico is a country of inequalities. Since the 1950 s economists have devoted enormous time and effort to measure inequalities and design policies to decrease it. The purpose of this study is to trace the evolution of inequality since 1850 by using anthropometric measures as an indicator of living standards and inequalities. The findings show that in Mexico there were different trajectories in the evolution of biological standards of living of the population that mirror the evolution of inequality. The trajectories are defined by region, social strata, health condition (life expectancy), as well as participation in the process of economic modernization and growth, progress opportunities, and allocation/protection of property rights. The databases for the period 1850-1950 will allow us to identify three trends in living standards for three different social groups: the rich, the laboring classes who were integrated in the formal economy, and the remainder of the popular classes. The group at the top of the social ladder got taller over time. Despite political instability, economic stagnation, and poor state of public finances suffered during much of the second half of the nineteenth century, the better-off portion of the population experienced a living standard improvement until the first decades of the twentieth century. Working-class people inserted in the formal economy also grew taller albeit they were shorter than the elite. In contrast, during the second half of the nineteenth century, the great majority of the population belonging to the lower income levels underwent a gradual deterioration in their biological standards of living. For most of the 1850-1950 period, the living standards of the largest portion of the popular

\author{
M. López-Alonso ( $\square)$ \\ Rice University, Houston, TX, USA \\ e-mail: moramay@rice.edu \\ R. Vélez-Grajales \\ Centro de Estudios Espinosa Yglesias, Ciudad de México, Mexico \\ e-mail: rvelezg@ceey.org.mx


classes do not coincide with the evolution of GDP per capita. Neither do they coincide with the evolution of living standards of the middle and upper-middle classes. Regional comparisons show that, in general, people from the north and center-north (bajio) of the country were taller than people from the center and south.

The analysis for the period 1951-1992 is based on the work by Vélez-Grajales (2016), which is an extension of the study by López-Alonso and Vélez-Grajales (2015). ${ }^{1}$ In particular, in comparison with the previous study, in the present one the covered period is extended from 1986 to 1992, and female height estimations for the post-1950 period are also included. Results show a constant positive trend on heights since the late 1960s. The observed increases were not enough to converge on height levels of other similar economies (Brazil, Colombia) . Results suggest that there is a rural penalty. And even more, estimations show that education disparities make significant differences in height. Moreover, the socioeconomic inequality captured by school attainment differences is even deeper for females. Once the social stratification that characterizes Mexico is taken into account, it is easier to understand why average height increases have been moderate. Finally, and based on the historical periods analyzed in the present study, we trace a long-run height trend from 1850 to 1992 . The exercise, made only for males, shows a trend with almost a W-shape.

The study is organized as follows. In Sect. 2 we present the sources and methods with which human stature can be used as a proxy for living standards and how this measure also assesses inequality. In the third section we examine the period 1850-1950. The fourth section analyzes trends in height for the post-1950 period. The fifth section concludes.

\section{Sources and Methods}

There are several methods to measure changes in living standard and income distribution over time. Anthropometric methods, that use height and body mass, is one way of looking at the evolution of living standards and income distribution. Height can be used as a proxy of well-being because the final height of an adult is the result of the interaction of several variables, which are all related to income. ${ }^{2}$ These interactions make it a multidimensional measure of well-being as it assesses the effect of nutrition, health, education, and income on living standards. The logic behind this is as follows: if people during their childhood years have a good nutrition, adequate clothing, and reasonable shelter, and receive some schooling, they are more likely

\footnotetext{
${ }^{1}$ López-Alonso and Vélez-Grajales (2015) "Measuring Inequality" and Vélez-Grajales (2016), The Biological Standard of Living During Post-Revolutionary Mexico.

${ }^{2}$ Timothy Cuff, The Hidden Cost of Economic Development: The Biological Standard of Living in Antebellum Pennsylvania (Burlington, VT: Ashgate Publishing Company, 2005), 10-11; Kenneth Sokolff, "The Heights of Americans in Three Centuries: Some Economic and Demographic Implications," in The Biological Standard of Living on Three Continents: Further Explorations in Anthropometric history, ed. John Komlos, (Boulder, CO, Westview Press, 1995), 134.
} 
on average to grow taller than those people who, despite having the same genetic endowment, grow up under less favorable conditions (Steckel 1995, 1998). Not being fed by one or several of these inputs puts an individual at a disadvantage to fully develop his/her height potential. Thus, in a given society, people from richer income strata would be taller than people from poorer income strata. Due to its multidimensional nature, and even though there is a vast literature on the subject, there is no widely accepted model of income based on heights. ${ }^{3}$

Two additional points give relevance to height as a measure of living standards and income distribution. First, in pre-monetized societies the use of statures is one valid way to measure living standards. In the case of agrarian societies where peasants receive their income in kind or in the consumption of their own production, it is difficult if not impossible to estimate incomes. Second, heights are observable in all societies, providing us an easier way to draw comparisons at the international level and over time, as economies experienced transformation of the productive processes. The challenge would be to have the data availability but other measures of well-being share the same challenge. Also, due to its nature, arranging adults by cohort allows us to do longitudinal analysis with a single cross-section data source.

Some economic historians, however, argue that even if heights are a robust indicator of health and well-being it cannot be taken for granted for all periods and regions, and moreover, that its usefulness could fade in the future. ${ }^{4}$ They also clarify that heights can be a useful measure to analyze the effectiveness of social policy, to assess well-being in societies that still struggle with income inequality issues, and for countries that may suffer from very poor and incomplete data collection. ${ }^{5}$

Mexico is one case where adult heights remain a valuable proxy to assess wellbeing and inequality. This approach allows us to examine the effects of political transformations and the effectiveness of social policies intended to decrease inequality. The data sources for the analysis are more than just a single one. For the 18501950 period, data will be drawn from sources normally used for historical studies, namely military and passport records. ${ }^{6}$ For the post-1950 period, we will use national statistics; this is the 2000 Mexican National Health Survey (ENSA-2000) and the 2006 and 2012 Mexican National Survey on Health and Nutrition (ENSANUT-2006 and ENSANUT-2012). ${ }^{7}$ These are all national probabilistic surveys, conducted by the Instituto Nacional de Salud Pública and were designed

\footnotetext{
${ }^{3}$ For some examples on modeling the relationship between height in income variables see Steckel, "Height and Per Capita Income" (1983), Brinkman et al. "Height and income: A new method for the estimation of historical national income series" (1988), and Coll, "The relationship between human physical stature and GDP (some experiments with European Time Series)" (1998).

${ }^{4}$ Timothy Leunig and Hans Joachim Voth, (2006) "Height and the High Life," in The Economic Future in Historical Perspective, p. 419.

${ }^{5}$ Idem, p. 431.

${ }^{6}$ To have more detailed information on the sources and methods for the 1850-1950 see LópezAlonso Measuring Up, Sect. 2, Chap. 1.

${ }^{7}$ To have more detailed information on the sources and methods for the post-1950 period see López-Alonso and Vélez-Grajales (2015) "Measuring Inequality" and Vélez-Grajales 2016, The Biological Standard of Living During Post-Revolutionary Mexico.
} 
to obtain information on accessibility, quality, coverage, and use of health services. Anthropometric measures such as height and weight are captured. ${ }^{8}$ The surveys were conducted in the 32 Mexican States.

\section{Living Standards and Inequality from 1850 to 1950}

This section examines the evolution of living standards in Mexico from 1850 to 1950 by tracking the trends in heights of the population samples presented in the previous section. This study focuses on the macro trends in long-term perspective. Acknowledging, however, that disparities across regions and across social classes are ubiquitous in Mexican history, it remains important to trace their evolution within this context as well. We will analyze the evolution of heights over time and make inferences on the evolution of biological standards of living and their correlation to the evolution of inequality. As we examine our data, we will indicate which of the independent variables that we are working with are the most important determinants of height. We will run the tests of the main sample of heights as well as of the subsamples (geographical, socioeconomic, literate/illiterate, urban/rural) to evaluate the differences among them in long-term trends. In this way, we can have an idea of the compositional changes of the population and their relationship with the average heights and the biological standards of living. ${ }^{9}$

Examining the trajectories in biological standards of living of different groups is also a way to analyze inequality in well-being. Human adult stature is an output variable that reflects the effects of nutrition, health, education, and income on living standards. Hence by analyzing the trends in stature across regions, social classes, and other categories we can also ascertain the evolution of inequality. Because height is a multidimensional variable we will not be measuring income inequality in living standards that encompasses a broader definition of quality of life; this would be measuring not only how much people make but also how well they spend it based on their knowledge of what enhances living standards.

Applying a regression analysis to the data that we gathered on the heights of the Mexican military, rural police, and passport records, we will be able to infer if there was a secular increase in the average height of the Mexican population for the cohorts born between 1850 and 1950; this will give us an idea of the evolution of the biological living standards of the entire population. ${ }^{10}$ We can also ascertain

\footnotetext{
${ }^{8}$ Individuals were measured with stadimeter.

${ }^{9}$ All these tests will be done with regression analysis techniques. The accuracy of the analysis corresponds to the quality of the data; as all anthropometric history literature explain, there will always be inaccuracies in the estimations due to data quality when compared to studies of the contemporary period. Notwithstanding, it has to be kept in mind that this is a common risk in all historical research. By determining the extent and direction of the biases inherent in the data by the use of standard techniques we can reach a higher level of accuracy.

${ }^{10}$ Anthropometric history literature defines "secular trend" in heights when there is an increasing trend in average heights over time when there are periods of economic growth.
} 
if there were different trends in height, or not, across regions and across social classes. As we mentioned earlier, there is no widely accepted model of income based on height. As a result, the majority of studies on anthropometric history define class in a more sociological way: by occupation or educational status.

\subsection{The Trend Analysis}

\subsubsection{The Military Samples ${ }^{11}$}

There is a downward trend in the height sample for the period 1850-1950. The 40-year period during which this downward trend lasted corresponds to people growing up during the second half of the nineteenth century and the first decade of the twentieth century; this suggests deterioration in living standards of the working classes during the last half of the nineteenth century. However, we should keep in mind that the rurales sample, in which we observe the decline, is drawn from a particular portion of the popular classes, farm hands and craftsmen, but not miners or factory workers. It was men who worked in trades that were being displaced by the introduction of the railroad or artisans driven out of business by machines and manufactures. ${ }^{12}$ For the most part these were men in the mid-30s, temporarily unemployed who enlisted in the rurales, until something better came along. Over time the height of this sample declined and this suggests that the biological standard of living of this portion of the popular classes was deteriorating, a reflection of what was happening in the sectors of the economy where they had worked prior to joining the rurales militia. The cause of this decline in height sheds light on how the end of the preindustrial era in Mexico affected certain portions of the population. The transformation of the economy fostered growth but, in the process, it also left some sectors of the population out of work; hence their standards of living deteriorated. ${ }^{13}$ This phenomenon can also be interpreted as increased inequality as a result of the modernization of the economy. Moreover, this trend is also indicative of a rise in inequality vis-à-vis those groups who did grew wealthier with the economic takeoff experienced in the last decades of the twentieth century.

There is a difference in trends between the rurales and the federales for cohorts born in the 1880s and 1890s for the regression results; this difference is driven by the number of observations for those decades in each sample. For the 1890s the number of rurales born in that decade aged 23 or more is particularly small; most of the observations for the decade correspond to young men who had not attained their final height. Let us remember that the rural police dissolved in 1913 after Francisco

\footnotetext{
${ }^{11}$ For a thorough discussion on how to overcome biases when working with military samples presented here see López-Alonso and Vélez Grajales, "Measuring Inequality," 2015.

${ }^{12}$ Vanderwood, (1981) Disorder and Progress: Bandits, police and Mexican development, 108-9.

${ }^{13}$ Kessing, (1969) "Structural Change in Early Development: Mexico's changing industrial and and occupational structure from 1895 to 1950," Journal of Economic History, 723; Alan Knight, The Mexican Revolution, vol. 1, Porfirians, Liberals and Peasants (Cambridge University Press, 1986), 79-80.
} 
I. Madero's assassination. The federal soldiers sample has a higher number of men 23 and older. Moreover, the recruits in the federales sample come from a wider variety of trades than their rurales counterparts (Table 1).

Traditional historiography asserts that the Díaz administration was detrimental to the living standards of the popular classes because of the capitalist development model with which economic growth was set in motion. This model was based on the exploitation of the laboring classes, and in the case of peasants, it also meant the seizure of lands. ${ }^{14}$ Nonetheless, the evidence presented here suggests that the decline in standards of living began little over two decades before the Díaz dictatorship was actually inaugurated; thus, Porfirian administration policies could not have been the only reason for this decline. Political instability, transformation of modes of production that marked the end of the preindustrial era and displaced people from their traditional occupations, dire circumstances in the public finances, and disentailment of communal peasant properties were all causes of this decline.

The federales military sample covers a period that includes generations growing up during the Porfiriato, the revolution, and the first decades of the postrevolutionary period. Changes are not as steep as one would expect in a period marked by so many changes and instability. The first three decades covered in this sample show stagnation that would correspond to cohorts born during the last decade of the dictatorship and the revolution, with a decline in average statures for those born and growing up in the 1910s and 1920s. The last three decades of the period display a recovery trend that accelerates during the 1940s, which coincides with a period of growth for the middle classes, rapid population growth, and stagnation of the lower income strata.

In terms of evolution of biological standards of living there does not appear to be any significant deterioration due to the dictatorship that allegedly induced pauperization of the lower classes; the improvement observed for cohorts born toward the end of the Díaz period is modest compared to its economic performance that generated prosperity for the higher income strata. Industrialization processes taking place and economic growth did not produce an improvement in the quality of life of populations from which the army was getting its recruits. This evolution in the average height of soldiers is understandable given that industrialization at its early stages does not necessarily translate into an improvement in the biological standards of living of a population. ${ }^{15}$ In addition, as we mentioned earlier, changes in land tenure were not conducive to improving the livelihood of the average peasant. All these suggest that economic modernization did not narrow the gap in living standards across social classes.

The average stature of recruits born in the 1910s decade decreased; these are people growing up and during the revolution and the first decades of the postrevolutionary period. It is not surprising to observe a decline. It might, however, be surprising that the decline is not steeper given the chaos created by the years of armed

\footnotetext{
${ }^{14}$ Alan Knight, The Mexican Revolution, vol. 1, Porfirians, Liberals and Peasants (Cambridge University Press, 1986), 79-80.

${ }^{15}$ Steckel, (1995) "Stature and the Standard of Living"; Komlos, (1998) "Shrinking."
} 


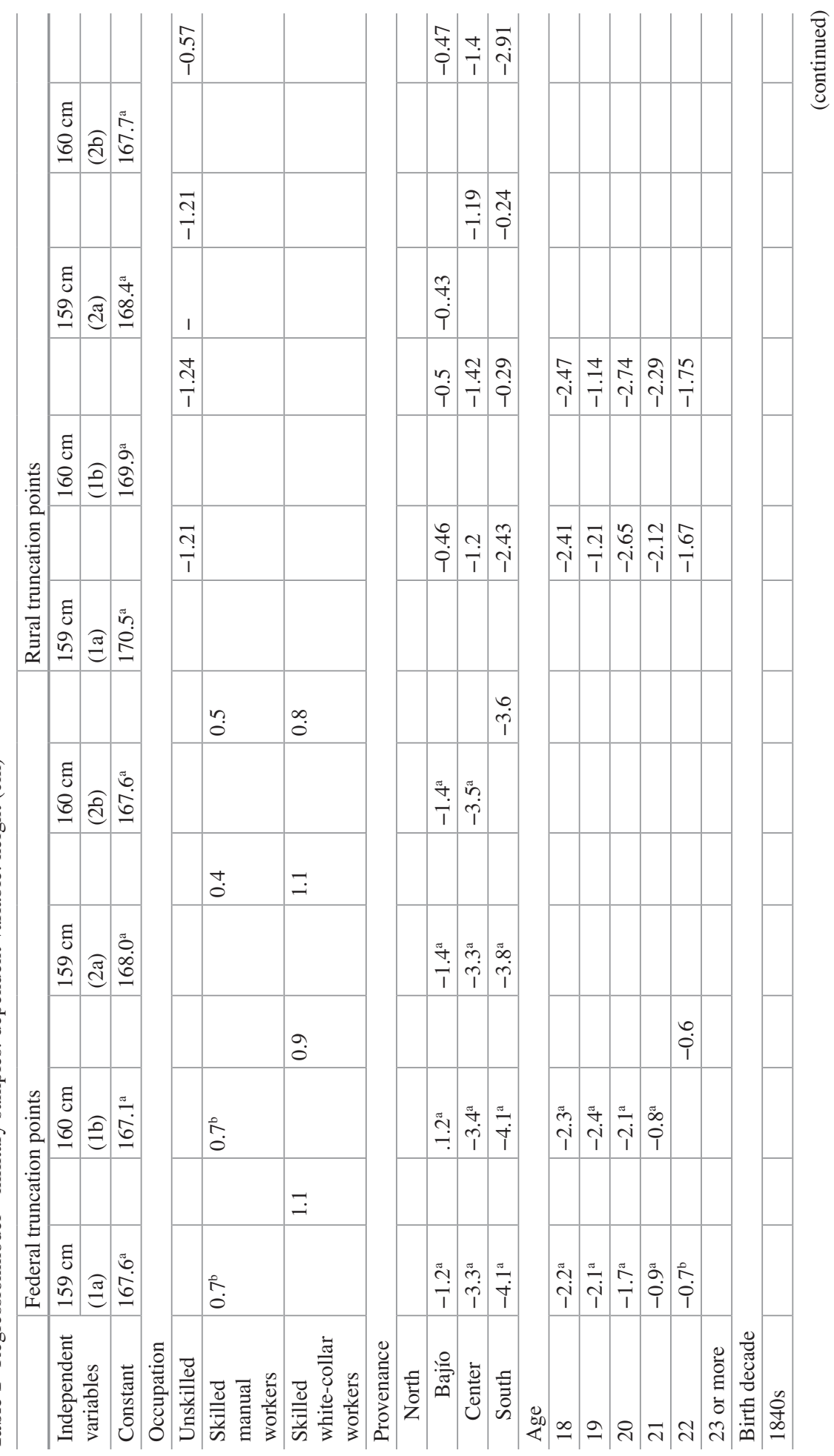




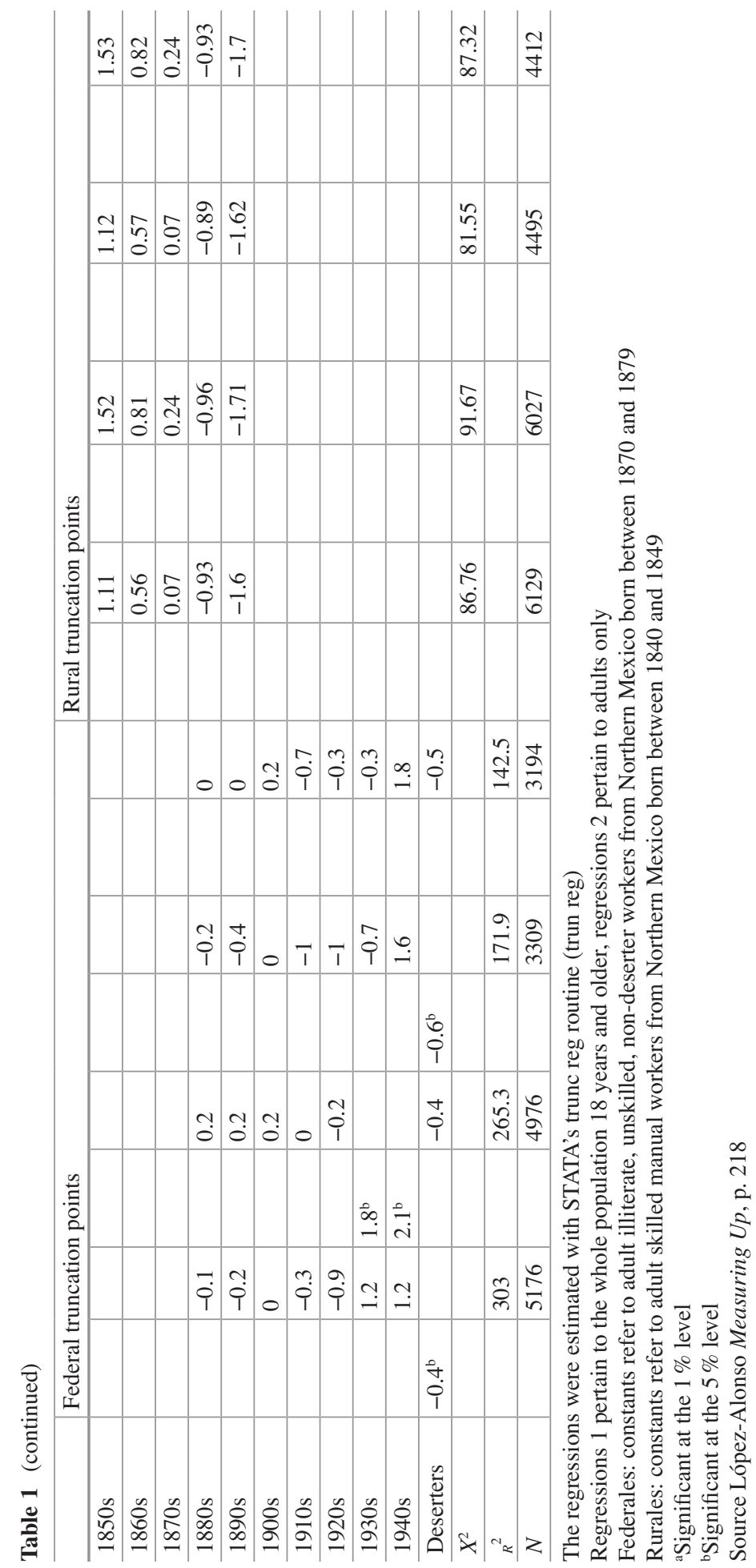


rebellion. After all, this was a violent war that took a heavy toll in human life. One explanation for this could be formulated under the Malthusian postulate that anything that raises the death schedule, for example, war, disorder, disease, or poor sanitary conditions, will increase material living standards. A fixed amount of resources is distributed among fewer people. Although this postulate applies to preindustrial societies, given that industrialization was only taking place in a small number of regions compared to the extent of the Mexican territory, we would argue that in this case the Malthusian argument holds.

The high death rate increasing material living conditions hypothesis is compatible with the meager recovery in stature observed for cohorts born during the following two decades. Still, this seems too meager a recovery for a revolution based on the granting of worker's rights and the undertaking of an agrarian reform. The improvement observed in living standards is rather deceptive and suggests that institutional reforms mandated by the 1917 constitution were meant to favor the popular classes but were only enforced to ameliorate the lives of a reduced portion of the working classes, namely those inserted in the formal economy.

In contrast, the substantial increase in average stature for cohorts born during the late 1930s and 1940s coincides with the launching of a welfare state and with government's commitment and recognition of its responsibility to assist the poor during the Lázaro Cárdenas administration, especially with the introduction of universal public health initiatives, such as national vaccination campaigns for children. The social development that stemmed from this commitment appears to have yielded positive results in the standards of living of the population from which the military were enlisting their recruits in the mid-twentieth century. We can then argue that there was a reduction in inequality in living standards starting in the 1930s.

With regard to regional disparities and differences across social classes in these samples, we can say that regression results for both samples are consistent. Recruits born in the north and Bajío are taller than their counterparts in other regions. Enlisted soldiers who were originally from the central and southern regions were shorter, with the exception of Mexico City and Veracruz, which were more economically dynamic regions than many parts of the center and south at the time.

Environmental differences play a relevant role, too. The north and Bajío had lower densities of population and were big-cattle-raising regions. Lower densities of population meant a lower exposure to diseases and epidemics. Throughout history, it has been observed that hunter-gatherers, seminomadic groups, and communities living in small settlement were less likely to be exposed to infectious diseases and epidemics; hence, their health tended to be better in general than that of sedentary communities. ${ }^{16}$ Regions that have significant cattle production normally will have a higher meat intake in their diet and will sell meat at relatively lower prices than regions that do not raise cattle. Traditional diet in the northern and Bajío regions was richer in animal protein, and this had a positive impact on final adult statures.

\footnotetext{
${ }^{16}$ For a more thorough discussion on the synergies between health, nutrition, and living standards see Measuring Up, Sect. 3 Chap. 1.
} 
Regression results also show that in both samples unskilled workers are slightly shorter than skilled workers. Such height differences suggest that men who had a trade were taller than those who did not. Being trained in a trade results in a form of human capital that correlated positively with a better biological standard of living.

\subsection{Passport Sample}

The stature of passport applicants increased throughout the period covered in this sample. The heights of applicants were also comparable to average heights of samples of males from the Western World. Such improvement suggests that men in this sample were not affected by the urban penalty of growing cities or the disentailment and privatization of communal property in the countryside. In contrast, it makes one think that the men in this sample benefited from all the positive transformations that were taking place, such as economic growth, investments in sanitary infrastructure, professionalization of medical services that allowed for more accurate diagnoses and prevention of most common infectious diseases, and, last but not least, better nutrition due to the increased availability of a wider array of foodstuffs.

Unlike other studies that use medical services as a determinant of human development, in this part of the study we do not make a more specific measurement of inequality in living standards with respect to health care services because of the profound transformation of the medical profession during this period and public health services. ${ }^{17} \mathrm{~A}$ brief glance at the history of medicine in the world and in Mexico will show us that medicine did not become a more scientific profession at the end of the nineteenth century; vaccination campaigns did not begin to have substantial impact on infant mortality until the 1920s; and it is not until the adoption and widespread availability of antibiotics that infectious diseases - closely correlated to malnutrition and poverty - we finally reduced. Medical services could only be afforded by well-to-do people and doctors tended to live in cities for the most part. Most rural areas had no doctors and even in those places where there were doctors, there was little they could actually cure until the 1940s. Having access to sanitary infrastructure and a good balanced nutrition was a stronger determinant of better health. $^{18}$

There is a regional disparity in this sample of the same nature as the military sample. This means that among passport applicants, males for the south and center were shorter than their Bajío and northern counterparts. ${ }^{19}$ There are disparities across social classes, but the gap tends to narrow over time; the elite and white-collar

\footnotetext{
${ }^{17}$ See Campos Vásquez and Márquez “Long-Run Human Development in Mexico 1895-2010” in this volume.

${ }^{18}$ For a more detailed discussion on the relevance of the medicine in the evolution of living standards see López-Alonso 2012, Sect. 3.

${ }^{19}$ Let us not forget that there is an undercount of people from border states in this sample.
} 
Table 2 Regression model for passport applicants

\begin{tabular}{|c|c|c|c|c|c|c|c|c|}
\hline \multirow{2}{*}{$\begin{array}{l}\text { Independent } \\
\text { variables }\end{array}$} & \multicolumn{2}{|l|}{ Males } & \multicolumn{2}{|l|}{ Females } & \multicolumn{2}{|l|}{ Males } & \multicolumn{2}{|l|}{ Females } \\
\hline & (1a) & & (1b) & & (2a) & & (2b) & \\
\hline \multicolumn{9}{|l|}{ Unskilled } \\
\hline $\begin{array}{l}\text { Skilled } \\
\text { manual } \\
\text { workers }\end{array}$ & $0.93^{\mathrm{b}}$ & & $1.22^{\mathrm{a}}$ & & $0.84^{\mathrm{b}}$ & & $1.01^{\mathrm{a}}$ & \\
\hline $\begin{array}{l}\text { Skilled } \\
\text { white-collar } \\
\text { workers }\end{array}$ & $1.21^{\mathrm{b}}$ & & $0.62^{\mathrm{b}}$ & & $1.06^{\mathrm{b}}$ & & $0.41^{\mathrm{a}}$ & \\
\hline Elite & $2.45^{\mathrm{a}}$ & & $1.32^{\mathrm{a}}$ & & & 2.33 & $1.04^{\mathrm{a}}$ & \\
\hline North & $2.82^{\mathrm{a}}$ & & $2.53^{\mathrm{a}}$ & & $2.59^{\mathrm{a}}$ & & $2.32^{\mathrm{a}}$ & \\
\hline Bajío & $2.11^{\mathrm{a}}$ & & $1.66^{\mathrm{a}}$ & & $2.04^{\mathrm{a}}$ & & & 1.57 \\
\hline Center & $1.37^{\mathrm{a}}$ & & $0.81^{\mathrm{b}}$ & & $1.18^{\mathrm{a}}$ & & & 0.64 \\
\hline \multicolumn{9}{|l|}{ South } \\
\hline \multicolumn{9}{|l|}{ Age 18} \\
\hline Age 19 & & -0.77 & & -0.51 & & & & \\
\hline Age 20 & & 0.35 & & -0.67 & & & & \\
\hline Age 21 & & -0.15 & & -0.03 & & & & \\
\hline Age 22 & & 0.47 & & 0.1 & & & & \\
\hline Age 23 or + & & 0.54 & & -0.03 & & & & \\
\hline \multicolumn{9}{|l|}{ Born 1860} \\
\hline Born 1870 & & 0.96 & $2.54^{\mathrm{b}}$ & & & 0.95 & $2.59^{\mathrm{b}}$ & \\
\hline Born 1880 & & 1.15 & $3.97^{\mathrm{a}}$ & & & 1.14 & $4.01^{\mathrm{a}}$ & \\
\hline Born 1890 & $2.28^{\mathrm{b}}$ & & $4.85^{\mathrm{a}}$ & & $2.27^{\mathrm{a}}$ & & $4.89^{\mathrm{a}}$ & \\
\hline Born 1900 & $2.57^{\mathrm{b}}$ & & $5.16^{\mathrm{a}}$ & & $2.58^{\mathrm{a}}$ & & $5.23^{\mathrm{a}}$ & \\
\hline Born 1910 & $3.06^{\mathrm{a}}$ & & $5.13^{\mathrm{a}}$ & & $3.02^{\mathrm{a}}$ & & $5.15^{\mathrm{a}}$ & \\
\hline Born 1920 & $3.29^{\mathrm{a}}$ & & $5.62^{\mathrm{a}}$ & & (Dropped) & & & 8.59 \\
\hline Constant & $164.83^{\mathrm{a}}$ & & $153.50^{\mathrm{a}}$ & & $165.64^{a}$ & & $153.76^{\mathrm{a}}$ & \\
\hline$R^{2}$ & & 0.0235 & & 0.0277 & & 0.0229 & & 1.0286 \\
\hline$N$ & & 11,390 & & 5207 & & 9693 & & 4424 \\
\hline
\end{tabular}

Note: Method OLS, constants refer to adult unskilled workers, from the South of Mexico, born between 1860 and 1869

${ }^{\text {aSignificant at } 1 \%}$

${ }^{\mathrm{b}}$ Significant at $5 \%$

Source López-Alonso Measuring Up, p. 218

workers are taller than their unskilled and skilled manual counterparts, but there is a pattern of convergence (see Table 2).

What may raise some sort of conundrum is that the heights of all subsamples are increasing. Why are unskilled and skilled manual workers in this sample getting taller while their counterparts from the military sample are following a trend in the opposite direction? The answer is inequality across different groups; within the working classes there were differences in opportunities for advancement. There were groups who benefitted from institutional changes and others that did not. This applies to all groups, namely, skilled manual workers, unskilled workers, peasants, day laborers, and domestic servants. Passport applicants were individuals who 
could travel abroad legally, but for Mexicans going to the USA this was far from being the norm: they were literate, and had a birth certificate. They could be categorized as the aristocracy of the laboring classes. Most likely, these applicants were workers who did benefit from institutional transformations that granted them more rights and higher incomes, and these workers were not affected by the absence of a properly defined state welfare system. On the other hand, men from military samples were representative of a portion of the lower strata of the population different from passport applicants; recruits belonged to segment living with a great scarcity of resources. Except for recruits born in the 1940s, soldiers in our sample did not have to present a birth certificate upon recruitment, and a substantial number were illiterate. The average stature of passport applicants improved. Although they remained shorter than the better-off strata of the society, there is convergence in heights across social classes. This suggests that at least for the better-off portion of the working classes, the evolution of biological standards of living looked more promising, and access to sanitary infrastructure and a higher income, as well as the possibility of a better diet, did become a reality for them.

On the subject of inequality, these trends show dispersion among the different groups of the laboring classes, thus suggesting that the process of economic modernization and growth did not impact working classes the same way. Those workers inserted in the formal economy followed the same path as the upper income strata group. In contrast, those people working on trades negatively affected by the transformation of the economy were left behind and their biological standards of living stagnated or deteriorated at a time in which they could have potentially improved just by having access to sanitary infrastructure and by not being vulnerable to famines.

\subsection{Women's Statures}

In analyzing the trends in statures of the female sample, there are several points that need to be considered regarding sexual dimorphism, literacy, and urbanization. Sexual dimorphism concerns the differences between males and females. One difference is adult height. In a given population living under normal circumstances, women are on average $12-13 \mathrm{~cm}$ shorter than adult men. This is a consequence of a different timing in growth spurts, which leaves boys on additional 2 years of growth before the end of the spurt. ${ }^{20}$ Another difference pertains to resilience to environmental insults such as food shortages and diseases that could be caused by war, famines, or exposure to a new pathogen. Women's growth tends to be more resistant to deprivation than men's; therefore, gender difference in stature is relatively larger in good times and shrinks under bad conditions. ${ }^{21}$ In addition, females tend to

\footnotetext{
${ }^{20}$ Bogin, (2001) Growth of Humanity, 131.

${ }^{21}$ J.M. Prince and Richard H. Steckel, "Tallest in the World: Native Americans of the Great Plains in Nineteenth Century" (National Bureau of Economic Research Working Paper Series, Historical Papers No. 112, 1998), 10.
} 
recover more quickly from environmental insults than males: "similarly girls recover from growth arrest more quickly than boys. The physiological reason for this greater stability is not known." 22 We should then expect to find less variation in stature for female height samples.

All women in the samples are both literate and urban. Both of these features are representative of a somewhat privileged minority of the female population on both accounts. At that time Mexicans were mainly rural and literacy levels were approximately $30 \%$. Being literate in an urban environment in our samples is a potential advantage vis-à-vis their illiterate rural counterparts given that they had access to the sanitary infrastructure available at the time, they had the skills and access to make the most of the information on best hygienic practices, and they had the resources to implement their hygienic measures. ${ }^{23}$

In the passport sample there appears to be no substantial difference in heights across regions. Differences across social classes are smaller than in the male sample and they also show a convergence pattern. Sexual dimorphism can explain why differences are smaller than in the male sample and they also show a convergence pattern. Sexual dimorphism can explain why differences are smaller among women than among men. For biological reasons, stature variation among females is expected to be smaller, and basic material living conditions across social classes in this sample were not too strikingly different. This means that women from the upper and upper-middle classes had a substantially higher standard of living; working class women in this sample did have means to cover the basic material conditions for good health and nutrition.

By examining the trends of these different samples we conclude that there is not one single trajectory in the evolution of the biological standards of living for the period 1850-1950. Also, having different trajectories explains the patterns of inequality. The trajectory of the military samples (federales and rurales) declines, stagnates, and has a slight recovery, a slight decline, and then a substantial recovery that leaves cohorts born in the 1950s with a similar height to their counterparts that were born a century before. In contrast, the trajectory of the passport sample is one of constant increase. The military samples are built with working-class recruits from diverse backgrounds (agricultural workers, artisans, factory workers, etc.), whereas the passport sample is built with people from different income levels.

Comparing these trajectories in the evolution of standards of living with the economic performance during the same period would shed light on the degree of prevailing inequality in living standards at the time. One way to establish this comparison is to examine the evolution of GDP per capita (see Fig. 1) in contrast with

\footnotetext{
${ }^{22}$ Tanner, (1978) Foetus into man, 166.

23 "Hygienic education was promoted in books, magazines, fliers and through the free public and popular conferences, and certain doctors and hygienists wrote about medical practice or domestic hygiene in books in which they gave detailed information of what every member of society would have to do to preserve health and prevent diseases. According to the medical profession, women were natural allies to hygienist endeavors, mothers in particular since they had a misión of motherhood and children's education" (Claudia Agostoni, "Discurso médico, cultura higiénica y la mujer en la ciudad de México al cambio del siglo [XIX-XX], Mexican Studies/Estudios Mexicanos 18, no. 1 [Agostoni 2002]: 22).
} 


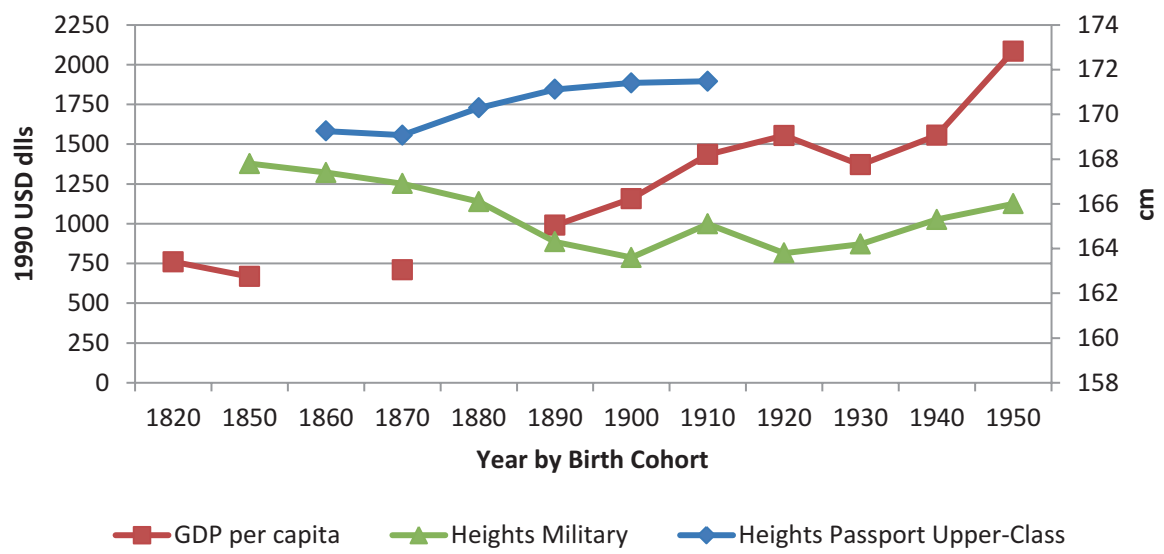

Fig. 1 Male height and Geary-Khamis GDP per capita (1990 USD)

that of heights of the different groups presented earlier. Passport samples follow a similar trend as GDP per capita follows opposite trends, such as for cohorts born and growing up during the second half of the nineteenth century. In contrast, there is a period when the average statures followed the same trend as GDP per capita, such as the cohorts born after the 1930s. These changes in correlation between GDP per capita and adult male average stature are plausible in light of the fact that economic growth does not necessarily improve the biological standards of living of a given population.

\section{Living Standards and Inequality After $1950^{24}$}

After the Great Depression, Mexico experienced a 40-year period of sustained economic growth. In particular, since the 1940s, the country shows GDP annual average growth rates over $4 \% .{ }^{25}$ It was until the 1980 s economic crisis when such positive trend stopped. In this section it is shown that heights also experienced a positive trend since the end of the 1960s. However, and given the existent inequalities in other dimensions different than GDP, it is also shown that height differences among socioeconomic strata have persisted. National improvements were not limited to economic growth. Life expectancy at birth, for example, grew from 34 years in 1930 to 49 years in 1950 , reaching 71 years by $1990 .{ }^{26}$ In the dimension of education, the national literacy rate in 1950 was of $64 \%$ and reached $87 \%$ by $1990 .{ }^{27}$ In the case of adult heights, the trend is also positive.

\footnotetext{
${ }^{24}$ This section is mainly taken from Vélez-Grajales (2016), The Biological Standard of Living During Post-Revolutionary Mexico.

${ }^{25}$ Marquez (2010). "Evolución y estructura del PIB, 1921-2010."

${ }^{26}$ INEGI. Indicadores sociodemográficos de México (1930-2000). México, 2001.

${ }^{27}$ PNUD, Informe sobre desarrollo humano 2002. México, 2003.
} 
Table 3 Regression results for female and male heights

\begin{tabular}{|c|c|c|}
\hline & Females & Males \\
\hline \multicolumn{3}{|l|}{ Birth cohort } \\
\hline 1951-1956 (omitted) & $\ldots$ & $\ldots$ \\
\hline $1957-1962$ & $-0.179(0.196)$ & $-0.083(0.286)$ \\
\hline $1963-1968$ & $-0.649 * * *(0.187)$ & $-0.411(0.275)$ \\
\hline 1969-1974 & $-0.453 * * *(0.180)$ & $0.319(0.265)$ \\
\hline $1975-1980$ & $-0.123(0.177)$ & $0.643 * *(0.270)$ \\
\hline $1981-1986$ & $0.268(0.187)$ & $1.157 * * *(0.277)$ \\
\hline 1987-1992 & $0.873 * * *(0.193)$ & $1.641 * * *(0.274)$ \\
\hline \multicolumn{3}{|l|}{ Education } \\
\hline Incomplete primary & $2.268 * * *(0.234)$ & $1.767 * * *(0.3745)$ \\
\hline Complete primary & $4.374 * * *(0.224)$ & $2.887 * * *(0.359)$ \\
\hline Secondary & $5.399 * * *(0.228)$ & $3.981 * * *(0.360)$ \\
\hline High school & $6.957 * * *(0.238)$ & $6.094 * * *(0.371)$ \\
\hline Bachelor & $8.255 * * *(0.290)$ & $7.160 * * *(0.412)$ \\
\hline Graduate studies & $9.208 * * *(1.056)$ & $7.016 * * *(1.087)$ \\
\hline No school (omitted) & $\ldots$ & $\ldots$ \\
\hline \multicolumn{3}{|l|}{ Current residence } \\
\hline Dummy for rural (1) & $-0.898 * * *(0.109)$ & $-0.805 * * *(0.149)$ \\
\hline Intercept & $148.926 * * *(0.244)$ & $162.122 * * *(0.394)$ \\
\hline$R^{2}$ & 0.104 & 0.080 \\
\hline$N$ & 19,649 & 12,797 \\
\hline
\end{tabular}

Standard errors in parentheses

Note: OLS regression

Source: Own estimations

$* 10 \%$

$* * 5 \% \mathrm{y}$

$* * * 1 \%$

\subsection{New Height Estimations and International Comparisons: 1951-1992}

A simple model of individual height determinants is estimated to obtain predicted average heights for the period 1951-1992. Once it is controlled for birth cohort dummies, variables for education attainment and current residence are included as determinants of height (see Table 3). As it is reported, birth cohorts are not making a significant difference. On the other hand, higher education levels and urban current residence result in taller individuals. ${ }^{28}$ The latter suggests that there is a rural penalty.

\footnotetext{
${ }^{28}$ For height estimation models $R^{2} \mathrm{~s}$ in regressions are always low. That happens because most of the variation in adult height is natural (genetic) and unexplained. John Komlos and Benjamín E. Lauderdale, (2007) "Spatial Correlates of US Heights," p. 63.
} 


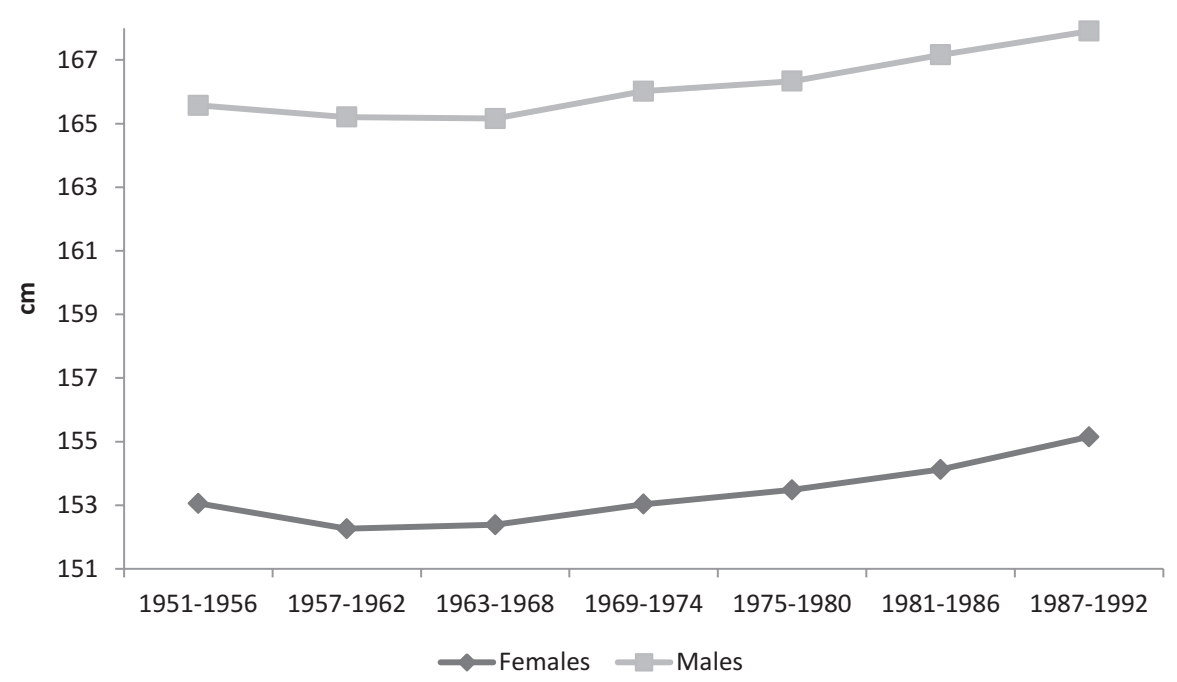

Fig. 2 Predicted national height (in cm) by 6-year birth cohorts, Mexico, 1951-1992 (National Surveys)

Table 4 Height comparison: Brazil, Colombia, and Mexico, by gender, 1951-1992

\begin{tabular}{l|l|l|l|l|l}
\hline \multicolumn{2}{l|}{ Birth cohort } & \multicolumn{3}{l|}{ Males } & Females \\
\hline & $\begin{array}{l}\text { Brazil- } \\
\text { Monasterio } \\
\text { et al. (estimated) }\end{array}$ & $\begin{array}{l}\text { Colombia- } \\
\text { Meisel and Vega }\end{array}$ & $\begin{array}{l}\text { Mexico } \\
\text { predicted) }\end{array}$ & $\begin{array}{l}\text { Colombia- } \\
\text { Meisel and Vega }\end{array}$ & $\begin{array}{l}\text { Mexico } \\
\text { (predicted) }\end{array}$ \\
\hline $1951-1956$ & 168.3 & 167.9 & 165.6 & 156.5 & 153.1 \\
\hline $1957-1962$ & 168.8 & 168.3 & 165.2 & 157.0 & 152.3 \\
\hline $1963-1968$ & 169.2 & 168.8 & 165.2 & 157.3 & 152.4 \\
\hline $1969-1974$ & 169.8 & 168.9 & 166.0 & 157.2 & 153.0 \\
\hline $1975-1980$ & 170.3 & 169.8 & 166.3 & 158.0 & 153.5 \\
\hline $1981-1986$ & & 170.6 & 167.2 & 158.7 & 154.1 \\
\hline $1987-1992$ & & & 167.9 & & 155.1 \\
\hline
\end{tabular}

Source: Mexico: own estimations; Colombia: Meisel and Vega (2007); Brazil: Monasterio et al. (2006)

In Fig. 2, both female and male height series are shown. In both cases, after a stagnation process during the $50 \mathrm{~s}$ and $60 \mathrm{~s}$, a constant and positive height growth took place. But how good was such performance? Was it sufficient in order to converge to other country levels? A simple comparison is made with other two Latin American countries: Brazil and Colombia. As we can see in Table 4, both Brazilian and Colombian males were and are still taller than Mexicans. In the same table a similar result is shown for the comparison between Mexican and Colombian females. Moreover, the gap for both males and females during the observed period was not closed.

The explanation for this poor performance can be related to inequality. In terms of income, in 1950 the highest state GDP per capita was more than six times bigger 


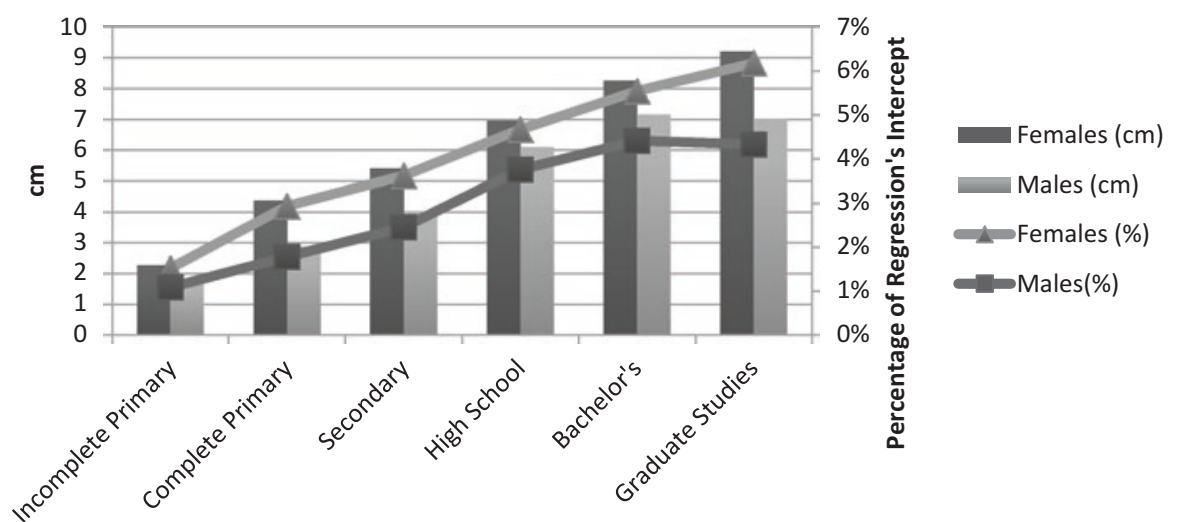

Fig. 3 The education penalty: no schooling versus other education levels

than the lowest one. By 1990 such difference was reduced, but it was still significant: a proportion of almost five to one..$^{29}$ In the case of literacy, in 1950 the highest state level rate was more than double the lowest one: 86 versus 39. By 1990, such difference was also reduced, but still, the difference was significant: 96 versus $70 \%$.

For the present analysis, it has to be noted that ENSA-2000, ENSANUT-2006, and ENSANUT-2012 were not designed to get retrospective information. Moreover, they do not include information on the place of origin (birthplace). Dimensions such as age, education, and location, however, are commonly good predictors of adult height. As a result, the OLS regression for heights in Table 3 includes a set of dummy variables: age (cohorts), educational attainment, and current rural-urban residence. Results show that socioeconomic differences that we can infer from education and location variables have repercussions on adult heights. The estimation shows that both rural females and rural males are shorter by around $0.8 \mathrm{~cm}$. Even more, education disparities make significant difference. As we can see in columns of Fig. 3, those females with no schooling are shorter than those with incomplete primary education by $2.3 \mathrm{~cm}$. The education penalty reaches $9.2 \mathrm{~cm}$ when the comparison is made between those with no schooling and those with graduate degree. For males, differences for both cases are $1.8 \mathrm{~cm}$ and $7 \mathrm{~cm}$, respectively. Absolute differences are larger among females, and such differences are even larger when they are estimated in relative terms (lines in Fig. 3). This result suggests that the socioeconomic inequality captured by school attainment differences is more profound for females.

These results beg the question: Has Mexico been capable to tackle the schooling inequality problem? One way to measure the effect of public policy in such a matter is by estimating the intergenerational mobility on education. As it is reported by Vélez, Campos, and Huerta (2013, pp. 32-34), "Educational coverage has widened over recent decades, and absolute educational opportunities for the Mexican people have increased along with it. However, ... it becomes apparent that educational

${ }^{29}$ Ibid. 


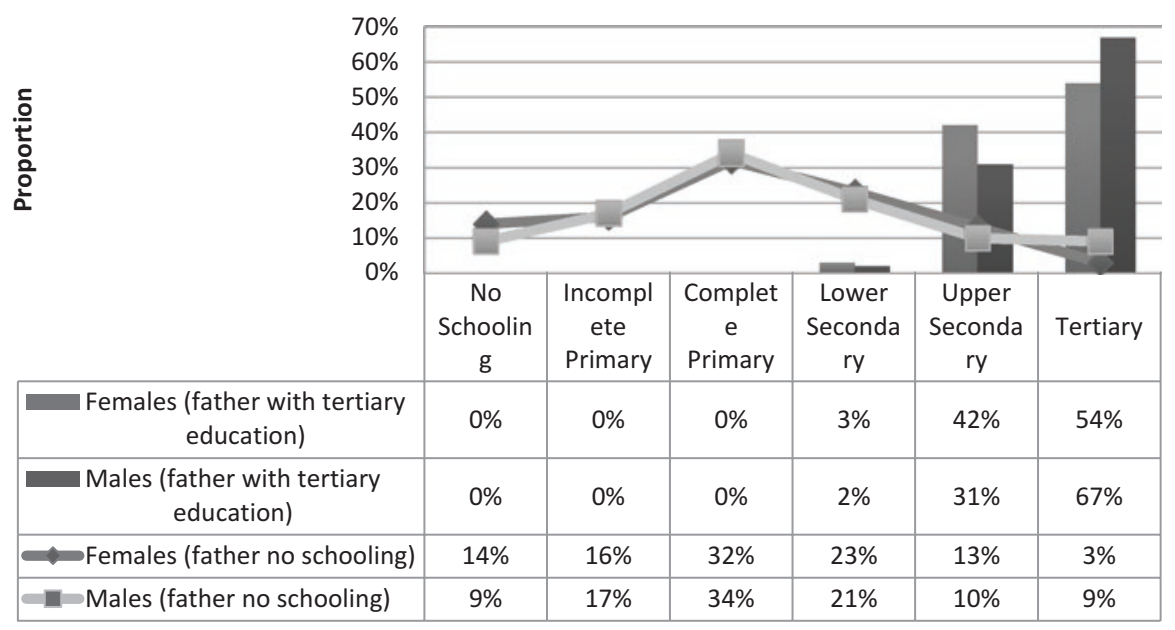

Fig. 4 Educational attainment by father's education level in Mexico, by gender: birth cohort 1947-1986

mobility in Mexico is limited at particular levels. For the first levels of education, primary and lower secondary school, socioeconomic origin has hardly any influence on achievement in higher levels of education. However, socioeconomic origin does affect achievement in upper secondary school and even more so in tertiary education." Moreover, as estimations on intergenerational mobility presented in Fig. 4 show, for the lower (lines) and higher (columns) ends of the spectrum, the probability of educational achievement conditional to father's education level is lower for females than for males. These results suggest that status quo, including gender inequality, persists in Mexico. In particular, firstly, there is a barrier related to socioeconomic origin that limits the options for women to reach upper secondary/ tertiary education for those coming from the lower end of the spectrum; this is women from a lower income level. Secondly, females coming from the lower end of the spectrum are less capable than their male counterparts to overcome such a barrier. And thirdly, even women from an upper income strata show a lower achievement rate in education than men of the same group. Once these results are translated into height trends, and given the social stratification that characterizes Mexico, it is easier to understand why average height increases have been moderate.

\section{Conclusion}

For the period 1850-1950, the evolution of living standards was heterogeneous across social classes mirroring inequalities in living standards. The trend in heights of the military tells a different story than that of the passport applicants. Passport applicants get taller over time. The military, on the other hand, experience 
deterioration and stagnation and do not recover their 1850s' height until 1950. There are regional disparities in both samples; the northerners and Bajio dwellers are taller than their counterparts in the center and south. Regional differences are larger in the military sample. Nonetheless, regional differences are not as marked as those across social classes; hence inequality in living standards across social classes is sharper than across regions.

The comparison in results between passport and military samples shed light on poverty and inequality issues. There are passport applicants from different social classes and, although the members of the upper strata are taller than applicants from the working classes, they all get taller over time and the gap between them decreases over time. This trajectory resembles the case of countries of the Western world where heights converge over time. This trajectory mirrors the evolution of the economy when we draw a comparison with per capita GDP. These results should be taken into consideration without losing sight of the fact that passport applicants represent a minority of the population and are not representative of the population at large. These were all urban, literate people who could afford to travel abroad legally. These three features are not common among the average Mexican born between 1850 and 1950 since the passport sample is representative only of the wealthy and of the small portion of the working classes that were favored by Mexico's economic growth and development during this period. Industrial development, export-led growth, and building of sanitary infrastructure contributed to the increase in stature of these passport samples. For the latter part of this period, it represents workers who did indeed benefit from the new labor legislation stemming from the 1917 Constitution. For those born and growing up during the decade of the Revolution's worst warfare (1910-1920), we observe that there is no height penalty. This suggests that these people were not hit by biological stressors such as food shortages and disease, so ubiquitous in places hit by warfare. The heights of working-class passport applicants can be used as a counterfactual hypothesis of what would have been the fate of the popular classes had the government's development policies also included efforts to integrate the population at large into the profound transformations that were taking place. The evolution of heights of the sample of women is similar to that of men. There is an increase over time.

The evolution of heights of the military samples reveals the impact on the great majority of the population of industrialization, displacement of traditional sectors of the economy, periods of political instability, and adoption of a development model that for the longest time gave little attention to human capital investments. The statures of the military recruits decreased for four decades (1850-1890); then they stagnated during the last decade of the nineteenth century. There is a modest improvement for the generation born around the turn of the century. This improvement is lost for the following generation; this reflects the penalty in living conditions for people who did endure the ravages of war during the Mexican Revolution. It should come as no surprise that the improvement in heights coincides with the launching of national-level public health campaigns as well as the launching of a welfare state in the late 1930s that reduced inequality in living standards; before then, the majority of the population was excluded from positive changes and lacked opportunities for advancement. 
Based on the ENSA-2000, ENSANUT-2006, and ENSANUT-2012, female and male average heights are estimated for the period 1951-1992. OLS regressions are used to estimate heights. Besides seven birth cohort dummies, variables on education and rural-urban residence are included in the regression. Results show that after a height stagnation during 1950s and 1960s, height growth continued until the end of the period of study. It has to be noted, however, that observed increases were not enough to converge to height levels of other similar (Brazil, Colombia) economies. Finally, in the case of females, Mexicans are still shorter than women from countries reported in the present study. Moreover, in comparison with Colombian females, the height gap is even bigger than for males.

Macro inequality in dimensions such as life expectancy at birth and education has been reduced, but there is still a significant gap. Results suggest that there is a rural penalty. Moreover, estimations show that education disparities yield significant differences in height. In addition, the socioeconomic inequality captured by school attainment differences is more profound for women. Based on evidence for levels of educational intergenerational mobility it is argued that status quo, including gender inequality, persists in Mexico. Once these results are translated into trends in height, and given that there is high social stratification in Mexico, it is easier to understand why average height increases were moderate for cohorts born between 1950 and 1992.

Finally, and based on the historical periods analyzed in the present study, it is possible to trace a long-run height trend in stature. Given the length of the 1850 1950 series, the exercise is made only for males. Results are presented in Fig. 5. For the 1850-1950 period, we use the military sample as one more representative of median Mexican. The whole trend shows an almost W-shape. There was a constant height decrease during the second half of nineteenth century. The decline did not stop until the late Porfiriato (1890s-1900s). However, due to the Mexican civil war in 1910 such improvement stopped, and it was just after the end of the civil war (circa 1920) and the Great Depression when the height trend became positive (1930s). In the 1950s and 1960s average height stagnated again, and it was only

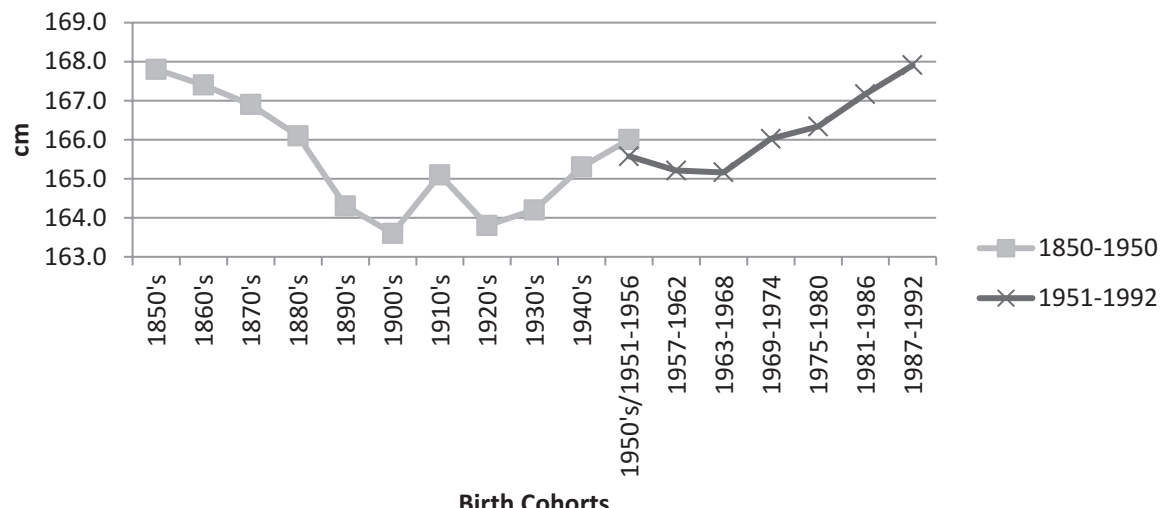

Fig. 5 Male mean height trends in Mexico, by birth cohorts: 1850-1992 
since the end of the 1960s when it experienced a constant increase until the end of the period of study.

For the post-1950 period further research is needed. Firstly, we still have to analyze the dynamics behind the 1950s' and 1960s' height stagnation. And secondly, even though it is not possible to control for birthplace, and therefore it is not possible to check for potential migration biases with ENSANUT, a deeper analysis on interregional differences than the one by López-Alonso and Vélez-Grajales (2015) is still needed.

Open Access This chapter is distributed under the terms of the Creative Commons Attribution 4.0 International License (http://creativecommons.org/licenses/by/4.0/), which permits use, duplication, adaptation, distribution and reproduction in any medium or format, as long as you give appropriate credit to the original author(s) and the source, a link is provided to the Creative Commons license and indicate if changes were made.

The images or other third party material in this chapter are included in the work's Creative Commons license, unless indicated otherwise in the credit line; if such material is not included in the work's Creative Commons license and the respective action is not permitted by statutory regulation, users will need to obtain permission from the license holder to duplicate, adapt or reproduce the material.

\section{References}

Agostoni, C. (2002). Discurso Médico, Cultura Higiénica Y La Mujer En La Ciudad de México Al Cambio de Siglo (XIX-XX). Mexican Studies/Estudios Mexicanos, 18(1), 1-22. doi:10.1525/ msem.2002.18.1.1.

Anand, S., \& Ravallion, M. (1993). Human development in poor countries: On the role of private incomes and public services. Journal of Economic Perspectives, 7(1), 133-150.

Baten, J. (2000). Economic development and the distribution of nutritional resources in Bavaria, 1797-1839. Journal of Income Distribution, 9(1), 89-106.

Baten, J., Pelger, I., \& Twrdek, L. (2009). The anthropometric history of Argentina, Brazil and Peru during the 19th and early 20th century. Economics and Human Biology, 7, 319-333.

Bogin, B. (1988). Patterns of human growth. Cambridge: Cambridge University Press.

Bogin, B. (2001). The growth of humanity. New York: Wiley-Liss.

Brinkman, H. J., Drukker, J. W., \& Slot, B. (1988). Height and income: A new method for the estimation of historical national income series. Explorations in Economic History, 25(3), 227-264.

Challú, A. (2009). Agricultural crisis and biological well-being in Mexico, 1730-1835. Historia Agraria, 47, 21-44.

Coll, S. (1998). The relationship between human physical stature and GDP (some experiments with European Time Series). In J. Komlos \& J. Baten (Eds.) Biological standard of living in comparative perspective. Contributions to the conference held in Munich, January 18-22, 1997, for the XIIth congress of the International Economic History Association (pp. 384-407). Stuttgart: Franz Steiner Verlag.

Cuff, T. (2005). The hidden cost of economic development: The biological standard of living in antebellum Pennsylvania. Aldershot: Ashgate Publishing.

David, P. A., \& Thomas, M. (2003). The economic future in historical perspective. Oxford: Oxford University Press for the British Academy. 
Eveleth, P. B., \& Tanner, J. M. (1990). Worldwide variation in human growth (2nd ed.). Cambridge, England: Cambridge University Press.

Floud, R. (1984, April). The heights of Europeans since 1750: A new source for European economic history. NBER Working Paper Series, No. 1318.

Floud, R., Wachter, K., \& Gregory, A. (2006). Height, health and history: Nutritional status in the United Kingdom, 1750-1980. Cambridge: Cambridge University Press.

Grajales-Porras, A., \& López-Alonso, M. (2011). Physical stature of men in eighteenth century Mexico: Evidence from puebla. Economics and Human Biology, 9, 265-271.

Haines, M. R., Craig, L. A., \& Weiss, T. (2003). The short and the dead: Nutrition, mortality, and the "Antebellum Puzzle" in the United States. The Journal of Economic History, 63(2), 382-413.

INEGI, Indicadores sociodemográficos de México. (1930-2000). México, 2001.

Keesing, D. B. (1969). Structural change early in development: Mexico's changing industrial and occupational structure from 1895 to 1950. The Journal of Economic History, 29(04), 716-738.

Knight, A. (1986). The Mexican revolution. Cambridge: Cambridge University Press.

Komlos, J. (1987). The height and weight of west point cadets: Dietary change in antebellum America. The Journal of Economic History, 47(4), 897-927.

Komlos, J. (1993). The secular trend in the biological standard of living in the United Kingdom, 1730-1860. The Journal of Economic History, 46(1), 115-144.

Komlos, J. (1995). The biological standard of living on three continents: Further explorations in anthropometric history. Boulder: Westview Press.

Komlos, J. (1998). Shrinking in a growing economy? The mystery of physical stature during the industrial revolution. The Journal of Economic History, 58(3), 779-802.

Komlos, J. (1999). On the nature of the Malthusian threat in the eighteenth century. The Economic History Review, 52(4), 730-748. New Series.

Komlos, J. (2004). How to (and how not to) analyse deficient height samples. Historical Methods, $37(4), 160-173$.

Komlos, J., \& Baten, J. (2004). Looking backward and looking forward: Anthropometric research and the development of social science history. Social Science History, 28(2), 191-210.

Komlos, J., \& Kim, J. H. (1990). Estimating trends in historical heights. Historical Methods, 23(3), $116-120$.

Komlos, J., \& Lauderdale, B. E. (2007). Spatial correlates of US heights and body mass indexes, 2002. Journal of Biosocial Science, 39, 59-78.

Leunig, T., \& Voth, H. J. (2006). Height and the high life. In P. A. David \& M. Thomas (Eds.), The economic future in historical perspective. Oxford: Oxford University Press.

López-Alonso, M. (2007). Growth with inequality: Living standards in Mexico, 1850-1950. Journal of Latin American Studies, 39, 81-105.

López-Alonso, M. (2012). Measuring up: A history of living standards in Mexico, 1850-1950. Stanford, CA: Stanford University Press.

López-Alonso, M., \& Condey, R. P. (2003). The ups and downs of Mexican economic growth: The biological standard of living and inequality, 1870-1950. Economics and Human Biology, 1(2), 169-186.

López-Alonso, M., \& Vélez-Grajales, R. (2015). Measuring inequality in living standards with anthropometric indicators: The case of Mexico, 1850-1986. Journal of Human Development and Capabilities, 16(3), 374-396.

Margo, R. A., \& Steckel, R. H. (1983). Heights of native-born whites during the antebellum period. The Journal of Economic History, 43(1), 167-174.

Martínez Carrión, J. M. (2001). Estatura, salud y bienestar en las primeras etapas del crecimiento económico español. Una perspectiva comparada de los niveles de vida. Documento de Trabajo, Asociación española de historia económica, DT-AEHE no. 102.

Meisel, A., \& Vega, M. (2007). The biological standard of living (and its convergence) in Colombia, 1870-2003: A tropical success story. Economics and Human Biology, 5(1), 100-122.

Monasterio, L. M., Nogueról, L. P. F., \& Shikida, C. D. (2006, June). Growth and inequalities of height in Brazil (1939-1981). Work presented in the Third Economics and Human Biology Conference in Strasbourg, France. 
Niewenweg, R., Smit, M. L., Walenkamp, M. J. E., \& Witt, J. M. (2003). Adult height corrected for shrinking and secular trend. Annals of Human Biology, 30(5), 563-569.

PNUD. (2003). Informe de Desarrollo Humano Mexico 2002. Madrid: Mundi-Prensa.

Prince, J. M., \& Steckel, R. H. (1998, December). The tallest in the world: Native Americans of the great plains in the nineteenth century. Working Paper. National Bureau of Economic Research.

Quiroga, G., \& Coll, S. (2000). Income distribution in the mirror of height differences: The case of Spain 1895-1950. Journal of Income Distribution, 9(1), 107-131.

Sen, A. (1985a). Commodities and capabilities. North-Holland: Amsterdam.

Sen, A. (1985b). Well-being, agency and freedom: The Dewey lectures 1984. Journal of Philosophy, 82(4), 169-221.

Sen, A. (1987). The standard of living. Cambridge: Cambridge University Press.

Sen, A. (2000). A decade of human development. Journal of Human Development and Capabilities, $1(1), 17-23$.

Sierra, J., \& O'Gorman, E. (1969). The political evolution of the Mexican people. With notes and a new introduction by Edmundo O'Gorman. Prologue by Alfonso Reyes (C. Ramsdell, Trans.). Austin: University of Texas Press.

Sokoloff, K. L. (1995). The heights of Americans in three centuries: Some economic and demographic implications. In J. Komlos (Ed.), The biological standard of living on three continents: Further explorations in anthropometric history (pp. 133-150). Boulder: Westview Press.

Sorkin, J. D., Muller, D. C., \& Andres, R. (1999). Longitudinal change in height of men and women: Implications for interpretation of the body mass index. American Journal of Epidemiology, 150(9), 969-977.

Steckel, R. H. (1983). Height and per capita income. Historical Methods, 16(1), 1-7.

Steckel, R. H. (1995). Stature and the standard of living. Journal of Economic Literature, 33(4), 1903-1940.

Steckel, R. H. (1998). Strategic ideas in the rise of the new anthropometric history and their implications for interdisciplinary research. The Journal of Economic History, 58(3), 803-821.

Tanner, J. M. (1978). Foetus into man: Physical growth from conception to maturity. Cambridge, MA: Harvard University Press.

Vanderwood, P. J. (1981). Disorder and progress: Bandits, police, and Mexican development. Lincoln: University of Nebraska Press.

Vélez-Grajales, R. (2016). The biological standard of living during post-revolutionary Mexico. Doctoral dissertation, University of Oxford.

Voth, H.-H., \& Leunig, T. (1996). Did smallpox reduce height? Stature and the standard of living in London. Economic History Review, 49(3), 541-560.

Voth, H.-H., \& Leunig, T. (2006). Height and the high life. In P. A. David \& M. Thomas (Eds.), The economic future in historical perspective. Oxford: Oxford University Press.

Wachter, K. W., \& Trussell, J. (1982). Estimating historical heights. Journal of the American Statistical Association, 77(378), 279-293.

Weber, G., Seidler, H., \& Hauser, G. (1995). Secular change in height in Austria: An effect of population stratification? Annals of Human Biology, 22(4), 277-288.

Moramay López-Alonso is an associate professor of History at Rice University. She is an economic historian of Latin America. She is the author of Measuring Up: A History of Living Standards in Mexico 1850-1950 (Stanford University Press 2012), winner of the 2013 Mexican History Book Prize awarded by the American Historical Association, and published in Spanish with Fondo de Cultura Económica in 2015. She holds a Ph.D. in History from Stanford University and a degree in Economics from Instituto Tecnológico Autónomo de México (ITAM).

Roberto Vélez Grajales is the director of the Social Mobility Program at the Espinosa Yglesias Research Centre in Mexico City. He is an Economist with doctoral studies in Modern History. His research interest subjects include social mobility, human development, and anthropometric history. On all these areas he has coordinated, authored, or worked as a consultant for several academic studies or public policy reports. 